\title{
«Ser señores de las Indias»: las agresiones inglesas al Caribe español, 1590-1620
}

por

\author{
Luis Rafael Burset Flores ${ }^{1}$ \\ Universidad Carlos Albizu
}

\begin{abstract}
A finales del siglo XVI, el imperio español en América habia sufrido derrotas militares y morales que mancillaron su prestigio como potencia mundial. Tras la fracasada invasión a Inglaterra en 1586, España perdió mucho más que su flota: perdió el respeto de los ingleses, quienes se embarcaron en un programa de ataques abiertos a las posesiones españolas en América. Este ensayo retrata la situación de las colonias en las décadas de cambio del XVI al XVII, y la desesperante vulnerabilidad del Caribe ante los ataques enemigos. Utilizando la correspondencia de los gobernadores y reales audiencias, el presente escrito presenta una mirada combinada de las incursiones a la región de varios agresores ingleses, unos más conocidos que otros.
\end{abstract}

Palabras clave: Ataques ingleses; corsarios; guerra; defensa; soldados; Drake; Cumberland; Caribe; siglo XVI; siglo XVII.

Cómo Citar Este Artículo / Citation: Burset Flores, Luis Rafael, “"Ser señores de las Indias»: las agresiones inglesas al Caribe español, 1590-1620", Revista de Indias, LXXXI/283 (Madrid, 2021): 635-667. https://doi.org/10.3989/revindias.2021.018.

El estado de guerra y alarma fue parte de la experiencia de vida en el Caribe, tanto en las islas como en el litoral de Centro y Sudamérica². Después de las intermitentes batallas para adueñarse y retener las tierras ocupadas por los pueblos indígenas, y de sus riquezas, la guerra se extendió a otros frentes:

${ }_{1}^{1}$ 1rburset@gmail.com, lburset@albizu.edu, ORCID iD: https://orcid.org/0000-0002-1439-2207

2 Adoptamos para la región la definición de Cuenca del Caribe, que, además de las islas, incluye el litoral caribeño del continente sudamericano, Centroamérica, el istmo de Panamá y la costa de México. Gaztambide Géigel, 2006: 44-47. Elliott, 2011: 49. 
los enemigos de España comenzaron a incursionar contra ciudades y puertos, retando su supremacía militar y su exclusivismo comercial. Con secuestros, saqueos y quemas, convirtieron al Caribe en un frente de batalla más. Por todo esto, Morales Carrión ha llamado «caos internacional» al periodo de cien años que terminó en $1625^{3}$.

En las primeras décadas del siglo XVI, el imperio español fue efectivo en la defensa de sus posesiones. No obstante, según pasó el tiempo y aumentaron los territorios ocupados, España se mostró incapaz de sostenerlo todo, a lo largo del tiempo. Ya para la primera mitad del XVII, España dejaría de ser una potencia militar relevante ${ }^{4}$. Se había extendido demasiado en el manejo de su imperio, facilitando el camino a los enemigos ${ }^{5}$.

Con el paso del tiempo, la política extranjera hacia España cambió de tónica e intención: de hacer daño, se pasó a establecer asentamientos permanentes en el Caribe. En 1580 se materializó la doctrina británica de ocupación efectiva, que reconocía a España únicamente la posesión de los territorios ya colonizados, dejando disponibles para ocupación los que no lo estuvieran ${ }^{6}$. Desde entonces, además de robar los tesoros y productos enviados por las colonias al puerto de Sevilla, y forzar o hacer trueques con los vecinos, los reinos extranjeros intentaron tomar territorio ${ }^{7}$. En este ensayo nos ocuparemos concretamente de las agresiones inglesas.

${ }^{3}$ Williams, 1984: 78, sostiene que los reinos protestantes veían la riqueza de las Indias como el sustento de la fe católica en Europa. Por ello, el francés Coligny recomendaba la política de atacar a España en las Indias para debilitarla en el continente. En su Jamaica Española, Morales Padrón, 2003: 25-26, 140 periodiza las agresiones por parte de los ingleses, acotando que estos reemplazaron a los franceses en los ataques a las posesiones españolas desde 1562, con el primer viaje de Hawkins, hasta 1595, con el ataque conjunto de este con Drake.

${ }^{4}$ Losada, 2015: 8-9.

5 Goodwin, 2016: 216.

${ }^{6}$ Williams, 1984: 72. Marrero, 1975: 87-88. Elliott subraya que la empresa americana por parte de los ingleses tuvo inicialmente un enfoque económico, en el que se tomó la colonización española como modelo (Elliott, 2011: 55-59). En 1610, el gobernador de La Habana notificó que, por la confesión tomada a un piloto inglés, se supo que en Inglaterra se había armado un filibote grande cargado de caballos, y doce navíos más de hombres y mujeres que venían a poblar la costa de la Florida; entre éstos venían canteros, carpinteros y herreros. Hace referencia al puerto llamado Vegina [Virginia]. Carta de Gaspar Ruiz de Pereda, gobernador de La Habana, 14 de abril de 1610, Archivo General de Indias, Sevilla (AGI), Audiencia de Santo Domingo (SD), 100, r. 3, n. ${ }^{\circ} 124$, f. 2.

${ }^{7}$ Morales Carrión, 2003: 79. Los primeros asentamientos fueron de los ingleses en Santa Lucía y en Granada en 1605 y 1609, respectivamente, que fracasaron por los ataques de los indios caribes; los holandeses se establecieron en San Eustacio en 1600, creando la Compañía Holandesa de la India Occidental en 1621. Los ingleses tendrán éxito en 1623 en San Cristóbal y en 1625 en Barbados. En 1617, Sancho Alquiza reportó el establecimiento de un 
Las relaciones entre Inglaterra y España en la segunda mitad del siglo XVI fueron, como mucho, frágiles. Tras el breve matrimonio de Felipe II con María de Tudor, empeoraron progresivamente. Un importante agravante fue el abrazo definitivo del protestantismo como la religión del Estado por parte de la reina Isabel I, media hermana y sucesora de María. Ya en 1583 el gobernador de Margarita señalaba las visitas indeseadas de ingleses, atraídos por las perlas ${ }^{8}$. La enemistad llegó a mayores cuando la Reina apoyó a los rebeldes de Flandes, a lo que España respondió ordenando el apresamiento de todos los barcos ingleses en puertos españoles en $1585^{\circ}$. Fue precisamente ese año cuando Isabel financió al infame Drake ataques a la costa de España, a Santo Domingo y a Cartagena de Indias ${ }^{10}$.

En 1588, Felipe II intentó derrocar a Isabel enviando su «Felicísima»armada, 1lamada posteriormente a manera de burla por los ingleses «invencible ${ }^{11}$, lo que terminó en un rotundo fracaso. Esta derrota no solo representó para España la pérdida de embarcaciones y hombres, sino también la de su prestigio y dominio sobre las aguas del mar. Ante la evidente vulnerabilidad de quien había sido hasta entonces dueño absoluto de las Indias, Isabel I aprobó un plan conocido como «Plan para Incordiar al Rey de España» ${ }^{12}$. La intención de tomar las Indias permanentemente a España surgirá en el siglo XVII bajo Oliver Cromwell, y sería llamado el «Designio Occidental» ${ }^{13}$.

Las agresiones inglesas no se hicieron esperar. Andrews contabiliza 74 proyectos ingleses con 183 barcos que navegaron al Caribe entre 1585 y 1603 , aparte de los de Drake. Añade otros 77 viajes entre 1589 y 1595, y 82 más de 1596 a $1602^{14}$. El corte temporal de nuestra investigación corresponde al segundo periodo de piratería en América (1569-1621) ${ }^{15}$.

De una y otra provincia española en el Caribe se sucedían incesantes informes de la presencia enemiga en sus aguas. Desde Santo Domingo y La

poblado de ingleses y flamencos en el río Guayapoco, cerca del Orinoco. Carta de Sancho de Alquiza, gobernador de La Habana, 17 de diciembre de 1617, AGI, SD 100, r. 5, n. ${ }^{\circ} 172$.

${ }^{8}$ Carta de Juan Sarmiento de Villandrando, gobernador de Isla Margarita, 9 de abril de 1583, AGI, SD 180, r. 2, n. ${ }^{\circ} 4$, f. $1 \mathrm{v}$.

${ }^{9}$ Marrero, 1974: 207.

${ }^{10}$ Moya Pons, 2008a: 67. Kris E. Lane presenta un interesante análisis de las prácticas de corsarios y piratas en la región, Lane, 2009: 105-124.

${ }_{11}$ Losada, 2015: 219. El nombre español oficial era Grande y Felicísima Armada.

12 Goodwin, 2016: 217. En inglés, Plan for The Annoying of the King of Spain. A este, Goodwin añade la salida de Drake a Cádiz en 1587 para «chamuscar la barba del rey de España».

13 Gardina Pestana, 2017: 7.

14 Andrews, 1978: 156.

15 Arráiz Lucca, 2013: 81. 
Habana se reportaba el avistamiento de unas 80 velas inglesas en $1591^{16}$, un dato pavoroso cuando se considera la dotación de soldados en los presidios de las islas ${ }^{17}$. Ese año, desde Puerto Rico se denunciaba «el atrevimiento y osadía con que los corsarios luteranos han infestado la mar estos pasados años», mientras el rey advertía al de Margarita que fortificara el puerto, y guardara las canoas de perlas y la hacienda real ${ }^{18}$. En 1593 se supo que seis navíos saldrían de Inglaterra para tomar los avisos que se enviaran o se recibieran de la Corte, obteniendo importante inteligencia sobre las Indias ${ }^{19}$. Ese año, el gobernador de Cuba reportó 20 velas enemigas que fueron sobre la costa de Tierra Firme, robando y quemando a Cumaná y a la Margarita ${ }^{20}$. Los años 1595 y 1596 debieron ser terribles, con las noticias de la toma de Puerto Rico - aunque temporal - y los ataques de Drake y Raleigh a las islas y litoral de Sudamérica y Panamá.

La presencia de enemigos se había convertido en parte de la cotidianidad en el Caribe. El cabildo de Santa Marta, a un año de la destrucción provocada por Drake a la ciudad, reportaba el ataque de otro corsario inglés: Anthony Sherley. En una frustrada y elocuente introducción, informaban al rey: «son tan ordinarios los trabajos que se padecen en este puerto por no tener defensa ni reparo, que tras una desgracia no hay sino esperar otra, y cada día mayor, porque crecen los atrevimientos de los enemigos, con la experiencia que van teniendo de nuestra poca fuerza y gente ${ }^{21}$. En 1595 , el presidente de la Audiencia de Santo Domingo informó que 31 frailes agustinos habían sido tomados por una lancha inglesa «que siempre está a la guarda de este puerto para que ni entre ni salga ningún navío» ${ }^{22}$.

La captura de ingleses en la isla de Pinos de Cuba en 1610 nos revela algunas de las rutas que seguían estos piratas. Salieron del río de Londres en julio de 1609 en dos navíos, uno de 100 toneladas, con 7 piezas de artillería, y

${ }^{16}$ Carta de Pedro de Lodeña, gobernador de Cartagena, 6 de septiembre de 1591, AGI, Audiencia de Santa Fe (SF) 37, r. 6, n. ${ }^{\circ} 103$.

17 Registro: Junta de Puerto Rico, 1586-1596, AGI, Indiferente General (IND) 521, 1. 1, fs. 90-92. Carta de Juan de Tejada, gobernador de La Habana, 29 de septiembre de 1591, AGI, SD 99, r. 18, n. $^{\circ} 160$.

${ }_{18}$ Ibidem, fs. 119-120.

19 Carta de Pedro de Lodeña, gobernador de Cartagena, 20 de abril de 1593, AGI, SF 37, r. 6 , n. ${ }^{\circ} 113$, f. 2.

${ }^{20}$ Carta de Juan Maldonado Barnuevo, gobernador de La Habana, 2 de noviembre de 1593, AGI, SD 99, r. 20, n. ${ }^{\circ} 175$, f., f. 1.

${ }^{21}$ Carta del cabildo secular de Santa Marta, 25 enero 1597, AGI, SF 66, n. 23.

${ }^{22}$ Carta de Lope de Vega Portocarrero, presidente de la Audiencia de Santo Domingo, 22 de octubre de 1595, AGI, SD 51, r. 17, n. 139. 
otro de 60, con cuatro, armados por el mercader inglés Richarte. En uno de ellos iba Cherpe, su factor. Llegaron a Margarita después de recorrer la costa de Guinea y haber pasado por la isla Trinidad. Echaron gente en Tres Puntas para cortar palo de brasil. El gobernador envió una canoa con gente a atacar a los ingleses, pero éstos fueron prevenidos por un indio. Los ingleses tomaron la canoa, mataron a su capitán y les quitaron las armas a los demás, a quienes dejaron ir. Desde la canoa, cogieron un navío portugués que iba de Cartagena a Cuba, en el que se perdieron. Se entendía que estos dos navíos habían pasado los meses anteriores en Santo Domingo y Puerto Rico, quedando en el Cabo de Tiburón (Cuba), donde tomaron un navío de negros, entre otras presas ${ }^{23}$.

Las historias generales del Caribe y las llamadas historias imperiales reconocen a importantes corsarios y piratas tanto ingleses, como franceses y holandeses. También se registran los principales ataques a ciudades y puertos en las historias nacionales ${ }^{24}$. No obstante, la correspondencia de los gobernadores y presidentes de las audiencias con la Corona, el Consejo de Indias, y entre sí, nos ofrece una mirada de primera mano, colectiva, de los ataques a las posesiones españolas. Relatan la preparación, o la falta de ella, los temores y las estrategias que siguieron para presentar resistencia que minimizara el daño, o para contratacar al enemigo ${ }^{25}$.

Para este ensayo, hemos cernido la correspondencia con la Corona y el Consejo de Indias de los gobernadores de La Habana, La Florida, Jamaica, Puerto Rico, Trinidad, Isla Margarita, Caracas, Cumaná, Santa Marta y Cartagena, y de los presidentes de las audiencias de Santo Domingo y Panamá, además de algunos cabildos, desde 1590 hasta 1620. Un tema recurrente en ellas es la insuficiencia de fortificaciones, armas, soldados y artillería: las ciudades eran vulnerables a los ataques enemigos por falta de preparación. En cada una de las tres décadas que componen el periodo de nuestro estudio, hubo solicitudes y advertencias a la Corona en relación a la necesidad urgente de defensas. En ocasiones, los soldados que se enviaban huían por el temor que habían tomado a las fuerzas inglesas ${ }^{26}$.

${ }^{23}$ Carta de Gaspar Ruiz de Pereda, gobernador de La Habana, 16 de abril de 1610, AGI, SD 100, r. 3, n. ${ }^{\circ} 124$, f. 1.

${ }^{24}$ Pinto Soria menciona el impacto de sus ataques en el establecimiento del puerto de Santo Tomás, en Guatemala, como el preferido en 1605, sobre los de Trujillo y Caballos, en Honduras, como resultado de los ataques de corsarios, incluyendo a Francis Drake y Thomas Cavendish. Pinto Soria, 1993: 129, 183.

${ }_{25}$ Carta del oidor licenciado Salazar, 22 de enero de 1596, AGI, Audiencia de Panamá (PAN) 14, r. 12, n. ${ }^{\circ} 68$.

${ }^{26}$ Petición del gobernador de Cartagena para que se le envíen recursos por la aproximación del corsario Francisco Drake, 1588, Archivo General de la Nación de Colombia, 
El sistema defensivo diseñado por Antonelli y Menéndez de Avilés había creado fortificaciones en puntos claves de la región para la protección de la región. Desde Venezuela se exaltaban en 1605 los beneficios de una fuerza propuesta para el puerto de La Guaira, el principal de la gobernación, que antes había sido «una ladronera de enemigos»" ${ }^{27}$. De Cartagena se pedía la construcción de otra en la Punta del Judío para proteger la ciudad y las flotas ${ }^{28}$; esta se materializaría. El de La Florida, por su parte, informaba que la de su ciudad estaba hecha de tablas, y que la madera estaba gastada, y faltaba clavazón. Como agravante, la dotación de soldados era de 300, cuando realmente se requerían $600^{29}$.

En 1590, el presidente de la Audiencia de Panamá anunciaba que los ingleses se jactaban que tomarían la ciudad con facilidad, y se lamentaba que lo que había en ella eran mercaderes que no sabían de cosas de guerra; éstos, ante noticias de ataques, abandonarían la ciudad, como ya lo habían hecho en Cartagena y Santo Domingo ${ }^{30}$. En 1594, el gobernador de La Habana reportaba que solo tenía 531 personas en total para defender la isla entre el Morro, la fortaleza vieja, el castillo de la Punta, y las compañías de dos capitanes ${ }^{31}$. El año siguiente, el de Puerto Rico escribía alarmado por la indiferencia de la Corona ante las peticiones de armamento ante las amenazas enemigas. Advertía que «si se perdiera por falta de esto, costará mucho trabajo para poderla ganar y restaurar $\rangle^{32}$. Desde Caracas, se advertía la falta de artillería en el puerto de La Guaira, que era la llave de aquella gobernación ${ }^{33}$.

Bogotá, Sección Colonia, Fondo Milicias y Marina, SC.37.35.3, f. 73. El gobernador Ludeña reportaba que varios de los soldados enviados con los capitanes Flores y Hoyos se habían huido, abandonando sus banderas, por lo que solo quedaban como 40 soldados entre las dos compañías.

27 Carta de Francisco Mexía de Godoy, gobernador de Venezuela, 27 mayo 1605, AGI, SD 193, r. 14, n. $^{\circ} 40$, f. 1.

${ }^{28}$ Carta de Jerónimo de Zuazo, gobernador de Cartagena, 28 de agosto de 1601, AGI, SF 38, r. 2 , n. ${ }^{\circ} 32$, f. $1 \mathrm{v}$.

${ }_{29}$ Carta de Juan de Treviño Guillamas, gobernador de La Florida, 1615, AGI, SD 225, r. 2, n. $^{\circ} 7$, f. 1 .

${ }^{30}$ Carta de Francisco de Cárdenas, presidente de la Audiencia de Panamá, 20 de junio

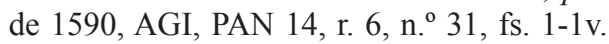

31 «Por las listas de la gente de guerra de los castillos de este puerto...», Carta de Juan Maldonado Barnuevo, gobernador de La Habana, 19 de agosto de 1594, AGI, SD 99, r. 20, n. ${ }^{\circ} 182$.

32 Carta de Pedro Suárez Coronel, gobernador de Puerto Rico, 19 de diciembre de 1595, AGI, SD 155, r. 12, n. ${ }^{\circ} 148$, f. 1.

${ }_{33}$ Carta de Sancho de Alquiza, gobernador de Venezuela, 20 de julio de 1606, AGI, SD 193, r. 15, n. $^{\circ} 44$. 
En 1599 en Panamá no se había recibido la artillería solicitada a la Casa de la Contratación para los castillos ${ }^{34}$. Para atender la limitación de artillería, el gobernador de La Habana sugirió que se le dejara la que sobrara de algunos de los galeones que se reunían en su puerto en su viaje de regreso a España ${ }^{35}$. En 1601, de Cartagena se solicitaban armas, municiones, artillería y gente para la galera guardacostas ante la noticia de que los enemigos de España se preparaban para «pasar a estar partes a hacer el daño que pudieren»; en ausencia de éstas, añadió «se ha de defender milagrosamente» ${ }^{36}$.

Ahora bien, cuando se recibían, la pólvora, municiones y cuerda podían ser insuficientes. Ante la salida de la armada inglesa hacia el Caribe en 1595, el presidente de la Audiencia de Santo Domingo pedía pólvora para aderezar las piezas de artillería: aunque la Corona le había hecho merced de 100 quintales, solo recibió 40 , y con éstas, tenía que proveer también a la fortaleza de Puerto Plata ${ }^{37}$. Por otro lado, las colonias tenían que competir entre sí por ellas. En 1595 Vega Portocarrero reportaba el progreso de las fortificaciones en esa ciudad, pero se lamentaba que, de la pólvora de la que se le hizo merced, sólo le entregó la mitad. La otra parte se le enviaría en el verano, pero el maestre la dejó en Cartagena con ropa que fue a vender allí38. En 1597, el gobernador de Cartagena refirió que a Santa Marta y al Río de La Hacha se habían enviado ocho piezas de bronce; llamándolas «lugarejos» incapaces de defenderse de un ataque de 70 u 80 hombres, descartó su necesidad, para pedir que se le depositaran a él las piezas con todos sus pertrechos y pólvora ${ }^{39}$.

Ante la aparente indiferencia de la Corona, en 1616 el gobernador Acuña insistía: «he dado cuenta a Vuestra Majestad del estado de las cosas de esta ciudad, y suplicado se me haga merced a mí y a ella de las de que hay necesidad para su guardia y fortificación, y hasta que Vuestra Majestad se sirva a mandar se tome resolución, lo continuaré, por lo mucho que importa la pre-

${ }^{34}$ Carta del presidente Alonso de Sotomayor, 18 de junio de 1599, AGI, PAN 14, r. 15, n. ${ }^{\circ} 111$, f. $4 \mathrm{v}$.

${ }_{35}$ Carta de Juan Maldonado Barnuevo, gobernador de La Habana, 19 de agosto de 1594, AGI, SD 99, r. 20, n. ${ }^{\circ} 183$, fs. 1v-2.

${ }^{36}$ Carta de Jerónimo de Zuazo, gobernador de Cartagena, 25 de mayo de 1602, AGI, SF 38, r. 2 , n. ${ }^{\circ} 36$, f. 1.

${ }^{37}$ Carta de Lope de Vega Portocarrero, presidente de la Audiencia de Santo Domingo, 20 de mayo de 1595, AGI, SD 51, r. 17, n. ${ }^{\circ} 134$, f. 1.

38 Carta de Lope de Vega Portocarrero, presidente de la Audiencia de Santo Domingo, 22 de octubre de 1595, AGI, SD 51, r. 17, n. ${ }^{\circ} 139$, f. 2 v.

${ }_{39}$ Carta de Pedro de Acuña, gobernador de Cartagena, 28 de julio de 1597, AGI, SF 38, r. 1, n. $^{\circ} 1$, f. 1 . 
vención a tiempo» ${ }^{40}$. A la altura de 1620 , el de Cumaná reportaba la poca defensa que había encontrado, además de estar necesitada de reparaciones; cinco piratas que andaban por las costas de Trinidad y Guayana los tenía «en harto cuidado respecto de la poca gente que hay para la defensa» ${ }^{41}$. Y poca había, porque hasta los soldados se tenían que distribuir para resolver necesidades inmediatas. En 1594, desde Puerto Rico llegó a Cuba el capitán Salazar con 54 hombres, que se repartieron entre La Habana, y La Florida ${ }^{42}$.

Como estrategia defensiva, los gobernadores pedían que la armada real pasara por las costas para amedrentar a los enemigos y obstaculizar sus planes de agresión. En 1597 el gobernador de Santa Marta y Río de La Hacha rogaba que no pasara de largo las ciudades de Tierra Firme en dirección a Cartagena, donde no hacía falta tanta defensa. Sugería que «vengan por la isla Margarita, recorriendo todos estos puertos de Barlovento, que no pierden tiempo, y en todos los del año hallarán corsarios y grandes ocasiones para hacer muchas presas ... pues el intento de Vuestra Majestad es que sus armadas limpien las Indias de enemigos ${ }^{43}$. Aunque lo hubiesen hecho, estas flotas pasaban una sola vez al año, lo que haría su protección insuficiente.

Otra muy similar estaba representada por las galeras, que, a pesar de sus propios problemas, fueron un recurso efectivo para limpiar las costas de enemigos. En 1601, capturaron el navío del capitán inglés Nicolao, que tomaba bastimentos de harina que se comerciaban entre las colonias ${ }^{44}$. El gobernador de Cartagena insistía en la necesidad de las galeras guardacostas para recorrer la costa hasta el cabo de la Vela y la isla de Curaçao, llegando hasta Santo Domingo, «donde de ordinario suelen recogerse e invernar los corsarios, y hacer sus salidas, que es causa para que no se puedan proveer las unas islas de las otras ni contratar con esta ciudad ni Tierra Firme $\rangle^{45}$. De Cumaná se lamentaban de la impunidad con la que centenares de barcos extranjeros llegaban hasta las salinas

${ }^{40}$ Carta de Pedro de Acuña, gobernador de Cartagena, 28 de julio de 1597, AGI, SF 38, r. 1, n. $^{\circ} 1$, f. 1 .

${ }^{41}$ Carta de Diego de Arroyo Daza, gobernador de Cumaná, 8 de junio de 1620, AGI, SD 187 , r. 6, n. $^{\circ} 35$, f. 1 .

${ }_{42}$ Carta de Juan Maldonado Barnuevo, gobernador de La Habana, 11 de julio de 1594, AGI, SD 99, r. 20, n. ${ }^{\circ} 181$.

${ }_{43}$ Carta de Francisco Manso de Contreras, gobernador de Santa Marta, 19 de junio de 1597, AGI, SF 49, r. 17, n. $^{\circ} 122$, f. $3 \mathrm{v}$.

${ }_{44}$ Carta de Jerónimo de Zuazo, gobernador de Cartagena, 29 de diciembre de 1601, AGI, SF 38, r. 2, n. $^{\circ} 33$.

${ }^{45}$ Carta de Pedro de Acuña, gobernador de Cartagena, 29 de marzo de 1595, AGI, SF 37, r. 7, n. $^{\circ} 135$. 
de Araya y las pesquerías de La Margarita ${ }^{46}$, pidiendo dos galeones con su fragatilla para poder proteger la costa de contrabandistas y corsarios ${ }^{47}$.

La situación había sido clara y repetidamente trasladada por las administraciones coloniales, y las soluciones presentadas a la Corona un sinnúmero de veces: pocos hombres, defensas inadecuadas, escasa artillería y pólvora; parecía que las provincias habían sido abandonadas a su suerte. Aun así, las solicitudes se seguían sucediendo unas a otras, y continuaban cayendo en oídos sordos año tras año. Parecería que la Corona española estaba resignada a perder su imperio.

A continuación, reseñamos los eventos relacionados a diez corsarios ingleses mencionados en la correspondencia cernida. Estos representarían 10 de las 74 empresas de agresión que reporta Andrews para este periodo. Hay gran diversidad entre los personajes en lo que se refiere a su fama, pero también en cuanto al daño que hicieron a las colonias; con miras a presentar un cuadro amplio de las agresiones inglesas al Caribe, los incluimos a todos por igual, organizados cronológicamente.

\section{El capitán JuAn de Bron, 1594, Cuba}

En este primer caso, la iniciativa de un gobernador consiguió capturar a los insistentes ingleses. En 1594, Juan Maldonado Barnuevo mandó a construir dos pinazas para combatir las lanchas que los enemigos echaban en tierra. Unos meses antes, el gobernador había reportado que 20 navíos ingleses en la costa de Tierra Firme habían robado y quemado a La Margarita y a Cumaná48. El 6 de julio capturó una, en la que iba el capitán Juan de Bron, «que lo es de un navío de los mejores y más bien en orden que este año han venido. Es hombre de importancia.... ${ }^{49}$. Al parecer, la presencia de Bron se limitó a la isla de Cuba, debido a que no aparece en la correspondencia de otros gobernadores de colonias en la Cuenca del Caribe para el periodo de interés.

${ }^{46}$ Carta de Diego Suárez de Amaya, gobernador de Cumaná, 15 de junio de 1602, AGI, SD 187, r. 3, n. ${ }^{\circ} 10$, f. 1. Reportó la presencia de 96 urcas que fueron a cargar sal, más otras 5 de rescate, además de los corsarios ingleses que rescataban perlas.

${ }^{47}$ Carta de Diego Suárez de Amaya, gobernador de Cumaná, 13 mayo 1603, AGI, SD 187, r. 3, n. $^{\circ} 13$.

${ }_{48}$ Carta de Juan Maldonado Barnuevo, gobernador de La Habana, 2 de noviembre de 1593, AGI, SD 99, r. 20, n. ${ }^{\circ} 175$.

${ }^{49}$ Carta de Juan Maldonado Barnuevo, gobernador de La Habana, 11 de julio de 1594, AGI, SD 99, r. 20, n. ${ }^{\circ} 181$, f. 1 . En su reseña sobre los corsarios ingleses que asediaron La Habana entre 1589 y 1595, Marrero no incluye a Juan de Bron, pero sí a los capitanes Sir John Watts, William Lane, John Myddelton, Richard Best, y Michael Geare, que no encontramos mencionados en la correspondencia. Marrero, 1974: 217-219. 
Cuando no eran ejecutados, los enemigos apresados se convertían en esclavos de las galeras, responsables de la guardia de las costas de Tierra Firme y de las Antillas. Si eran importantes, se pedía rescate por ellos, o se intercambiaban por españoles tomados presos por los ingleses ${ }^{50}$. Maldonado recomendaba no llevar a las galeras a los hombres de Bron, a quienes califica como «marineros comunes y gente de poca consideración», porque la pondría en riesgo, porque a diario se prendía mucha gente a los ingleses, y la tripulación de las galeras sería dominada por este enemigo ${ }^{51}$. Esta observación nos da una idea de la percepción que reinaba en las colonias sobre la presencia del enemigo inglés en sus aguas y su superioridad numérica.

El capitán Langton, 1593-1594, Margarita, Jamaica, Honduras, la ESPAÑola, Río DE EL HACHA

James Langton fue capitán del navío The Anthonie, de 120 toneladas, de la flota de George Clifford, Conde de Cumberland, en 1593. Estuvo en Santa Lucía y Martinica, llegó hasta isla Margarita, de donde robó perlas valoradas en 2.000 libras. En Cumaná fue rechazado, y pasó a La Española, donde robó y exigió rescates a cambio de españoles apresados. De ahí pasó a Jamaica y Honduras, regresando a Plymouth en $1594^{52}$. Había estado algunos días en Río de la Hacha y Santa Marta, sin desembarcar ${ }^{53}$.

Las cartas de varios gobernadores en las principales ciudades del Caribe nos presentan otra mirada a las hazañas de Langton. En 1594 se notificó a la Corte española que el capitán «Lanton» había permanecido más de dos meses sobre el puerto de Santo Domingo, y «reconociendo las pocas fuerzas de esta tierra, hizo grandes fieros, diciendo que había de volver este invierno con ocho o diez navíos para tomar la ciudad» ${ }^{54}$. En ese tiempo, tomó navíos y fragatas ${ }^{55}$.

${ }^{50}$ Este fue el caso del inglés Roberto Bost, que informó que la reina Isabel estaría dispuesta a intercambiarlo por don Alonso de Guzón. Carta de Pedro de Lodeña, gobernador de Cartagena, 15 de septiembre de 1592, AGI, SF 37, r. 6, n. ${ }^{\circ} 107$.

${ }^{51}$ Carta de Juan Maldonado Barnuevo, gobernador de La Habana, 11 de julio de 1594, AGI, SD 99, r. 20, n. ${ }^{\circ} 181$, f. 1.

52 Southey, 1827: 215-216.

${ }^{53}$ Méritos y servicios: Antonio de Melo: Nuevo Reino Granada, 1593, AGI, PAT 166, n. ${ }^{\circ}$ 4, r. 1, f. 426.

${ }^{54}$ Carta de Lope de Vega Portocarrero, presidente de la Audiencia de Santo Domingo, 20 de septiembre de 1594, AGI, SD 51, r. 16, n. ${ }^{\circ} 126$, fs. $1-1 \mathrm{v}$.

55 Carta de Lope de Vega Portocarrero, presidente de la Audiencia de Santo Domingo, 30 de enero de 1594, AGI, SD 51, r. 16, n. ${ }^{\circ}$ 120, f. 1. Carta de Simón de Meneses, oidor de la Audiencia de Santo Domingo, 20 de diciembre de 1594, AGI, SD 51, r. 16, n. ${ }^{\circ} 128$, fs. 1-1v. 
Afortunadamente, en esta ocasión, se habían recibido las armas y municiones enviadas por el rey, aunque la pólvora era poca, y de una nao portuguesa se habían sacado más de 500 balas, 30 piezas de artillería, arcabuces y mosquetes $^{56}$.

Lanton fue descrito como criado y hechura del Conde [Cumberland], basándose en informaciones obtenidas por un espía. Este corsario había recibido instrucciones desde Inglaterra de quedarse en Santo Domingo todo el mes de febrero porque Cumberland venía con 40 navíos. Desde allí partirían hacia La Habana a esperar las flotas de Nueva España con el dinero de Cartagena. Según se supo, Drake venía con otros 20 navíos, y entraría por la banda de la isla Margarita, corriendo la costa hasta Cartagena, donde se juntarían todos los navíos ingleses, 60 en total, en el cabo de San Antón ${ }^{57}$. La noticia debió sembrar el terror entre la población de Santo Domingo, puesto que ya Drake había saqueado la ciudad hacía menos de diez años.

Junto a otro corsario, Juan Bran, Lanton fue involucrado en unas acusaciones de contrabando que se hicieron contra dos vecinos de La Española, Antonio Ricardo Catalán y Juan Caballero Bazán, por unas cartas en las que se hacía patente su libre comunicación con los ingleses. Según se desprende de una de ellas, el capitán Lanton hablaba español claro, y había salido de Plymouth. Se mencionan los nombres de otros capitanes ingleses: Drake y Guillermo Finche, irlandés ${ }^{58}$. En el caso de Lanton, encontramos un ejemplo de un capitán inglés que combinaba el contrabando con vecinos principales con agresiones a las fortificaciones de la Isla.

\section{Walter Raleigh, 1595-1596: isla Trinidad y La Guayana ${ }^{59}$}

A Walter Raleigh se le atribuye haber comenzado el periodo de agresiones inglesas contra las posesiones españolas en el Caribe ${ }^{60}$. Raleigh había inten-

${ }^{56}$ Carta de Lope de Vega Portocarrero, presidente de la Audiencia de Santo Domingo, 20 de septiembre de 1594, AGI, SD 51, r. 16, n. ${ }^{\circ} 126$, fs. 1-1v.

57 Carta de Lope de Vega Portocarrero, presidente de la Audiencia de Santo Domingo, 30 de enero de 1594, AGI, SD 51, r. 16, n. ${ }^{\circ} 120$, f. 1.

58 Carta de Simón Meneses, oidor de la Audiencia de Santo Domingo, 20 de abril de 1595, AGI, SD 51, r. 17, n. ${ }^{\circ} 131$.

59 Thomas, 2013: 248-250. En estas páginas incluye un resumen de este ataque, con interesantes detalles sobre las intenciones de Raleigh. Por su parte, Raleigh publicó un libro titulado El descubrimiento de Guayana, en el que narra los detalles de esta empresa, http://www.gutenberg.org/files/2272/2272-h/2272-h.htm.

${ }^{60}$ Morales Padrón, 2003: 140. 
tado infructuosamente fundar una colonia en América del Norte con licencia de la Corona inglesa en $1585^{61}$, y finalmente se dirigió al sur en busca de las fabulosas riquezas que presuntamente se encontraban en aquellas latitudes, como no las había en el norte ${ }^{62}$. Raleigh representó la amenaza inglesa sobre el Caribe por la mayor extensión de tiempo, puesto que hasta el mismo año de su muerte anduvo por sus mares.

En 1595, Raleigh viajó directamente a la boca del río Orinoco, subiendo hasta 150 leguas río arriba. Allí intercambió objetos con un cacique, quien le mostró minas. Como prueba de su compromiso de volver, le dejó dos ingleses, y el cacique le dio un hijo y un sobrino a cambio. Raleigh volvería el año siguiente a poblar allí «para descubrir la yaguanana [sic] que está cerca». Regresó a Trinidad, donde tomó el fuerte, dejó un pendón de la reina, prendió al gobernador Berrío y degolló a los demás españoles ${ }^{63}$. Identificado como Mosiur Dacles Conde de Cornualla, capitán de la guarda de la reina de Inglaterra, surgió en el Puerto de España el 4 de abril de ese año. Llevaba cuatro navíos armados de infantería, cuatro lanchas y algunos barcos. Utilizando indios de esa isla y de Cumaná, unos traídos desde Inglaterra y otros tomados allí, se informó de la localización, las armas con las que contaban, y de la relación de los españoles con los indios.

Receloso de la amistad que habían entablado los indios naturales con el inglés, Berrío envió a su sobrino a reconocer su presencia y fuerzas. Bajo engaño, Rodrigo de la Hoz abordó la capitana con algunos hombres. Tras pasar tiempo sin dar noticias, Berrío envió más hombres en dos ocasiones. Éstos se negaron a abordar el barco, por lo que fueron agasajados en tierra por los ingleses. Finalmente, todos los españoles que tenían en el barco y en la playa fueron apuñalados, y 120 ingleses se dirigieron a la ciudad. Allí mataron españoles, quemaron la población, y tomaron prisionero al gobernador y a uno de sus capitanes, Álvaro Jorge. Solo pudieron escapar 17 soldados, algunas mujeres y un fraile franciscano, que se escondieron en los montes. Desde el puerto de La Brea, algunos navegaron en una piragua de «indios de paz» hasta la isla Margarita.

Los ingleses obtuvieron el apoyo de los indios bajo el pretexto de que los venían a libertar, con la condición de que reconocieran a la reina de Inglaterra como su Señora, cuya bandera ondeaba «en un palo muy alto». Decían que venían a tomar La Guayana, lugar del mítico El Dorado, por lo que bus-

\footnotetext{
${ }^{61}$ Cardelús y Fernández Toraño, 2013: 219. Elliott, 2011: 32.

${ }^{62}$ Elliott, 2010: 163; 2011: 147.

${ }^{63}$ Carta de Lope de Vega Portocarrero, presidente de la Audiencia de Santo Domingo, 22 de octubre de 1595, AGI, SD 51, r. 17, n. ${ }^{\circ} 139$, f. $3 \mathrm{v}$.
} 
caban copia de las cartas que Berrío recibía de la Corona; si no les daban esta información, lo entregarían a los indios para que lo flecharan, y al capitán Jorge para que lo ahorcaran. Los ingleses llevaron a ambos por el río Orinoco arriba. El ocho de junio llegaron noticias a la isla Margarita de que, con sus lanchas y gente, Raleigh había regresado del río Orinoco «muy contento». En la capitana no había rastros de Berrío ni de Jorge; se rumoraba que los habían enviado prisioneros a Inglaterra, o los habían muerto. Los ingleses construían un fuerte en Puerto de España y los indios "poblaban y vivían donde el coronel Berrío tenía el lugar».

El diez de junio amaneció un barco largo en el puerto de Pampatar de Isla Margarita, y más tarde, cinco velas enemigas más, «con muchas banderas, muchas barcas y pasajeros en torno de ellas». Se entendió que la intención era echar gente en el Puerto Moreno. El gobernador Salazar y su gente les impidieron bajar a tierra. Otro día aparecieron en la ranchería de las perlas más velas; esta vez sí pudieron echar gente en tierra, que fue rechazada, siendo apresados algunos ingleses, a quienes eventualmente se les tomaron informaciones.

Según relataron los prisioneros, habían traído planchas de oro del Orinoco dadas por los indios. Allí tuvieron «mucha confederación y amistad» con el cacique, quien les mostró una parte donde sacaban oro; llevaron cuatro pipas para hacer el ensaye en Inglaterra. Según relataron, regresarían el año siguiente con 1,500 hombres para poblar. Dejaron, además, un escudo de armas de la Reina, diciendo que antes de un año habrían de «ser señores de las Indias».

El gobernador de Margarita enviaba a Trinidad diferentes personas en una piragua para mantenerse informado de los sucesos. Por ellos se supo que Drake se encontraba en Plymouth preparando otra armada de 40 bajeles gruesos con 10.000 hombres y municiones de guerra, con planes de llegar a las Indias en agosto. Su plan era tomar Puerto Rico, Santo Domingo y Cartagena, «pero que el principal intento suyo es ir derecho a Panamá» ${ }^{64}$.

La toma definitiva de Trinidad por parte de los ingleses tendría que esperar doscientos años más. Tras salir de esa isla, intentó saquear Cumaná, siendo repelido y perdiendo más de 90 hombres ${ }^{65}$. Allí echó en tierra al gobernador Berrío. Tras su liberación, a mediados de julio de 1595, escribió sobre su experiencia con Guatarral, donde incluyó un relato en el que éste dijo a los soldados «...que él era católico cristiano y que sus padres habían muerto en

${ }^{64}$ Carta de Pedro de Salazar, gobernador de Isla Margarita, 10 de julio de 1595, AGI, SD 180, r. 3, n. ${ }^{\circ} 12$, f. 2-2v. Es de estos hombres que sale la crónica que el gobernador envió al rey.

${ }^{65}$ Carta de Lope de Vega Portocarrero, presidente de la Audiencia de Santo Domingo, 22 de octubre de 1595, AGI, SD 51, r. 17, n. ${ }^{\text {1 }} 139$, f. $3 \mathrm{v}$. 
la santa fe católica y que él pensaba imitarlos y que hasta allí había sido el hombre que más podía en Inglaterra y a quien más merced y regalo hacía la reina, y que ahora había que estaba en su desgracia dos años por haber empreñado una dama dentro de palacio y casado con ella» ${ }^{66}$.

Las andanzas de Raleigh no terminaron ahí. En julio de ese año, el presidente Vega Portocarrero informó que el conde «Guatarrali» había llegado al puerto de Ocoa, a 14 leguas de Santo Domingo ${ }^{67}$. Años más tarde, en 1617, se avisó al gobernador de Cartagena que tuviera cuidado y vigilara la costa para prevenir los daños que «Gualtero Reali» y otro enemigo intentaban hacer ${ }^{68}$. En 1618, el gobernador de Cumaná reportó un ataque de «Guatarral», donde mataron al gobernador Diego Palomeque y Acuña ${ }^{69}$. La vida de Raleigh terminó cuando fue ejecutado por traición por los mismos ingleses el 29 de octubre de ese año ${ }^{70}$.

\section{Sir Francis Drake, 1595-1596, Puerto Rico, Cartagena y Panamá}

Junto a Raleigh, Drake es uno de los corsarios ingleses más conocidos en el Caribe, por sus ataques a Panamá en 1572, Santo Domingo, Cuba y La Florida (ciudades de San Agustín y Santa Elena) en $1586^{71}$, y a Puerto Rico, Santa Marta, Río de la Hacha, Cartagena y Panamá entre 1595 y 1596 . Hakluyt lo describe como el primer inglés que se atrevió a aventurarse a las costas de Tierra Firme después del establecimiento de las galeras guardacostas de Cartagena, presentándose allí con 24 naves $^{72}$. Los ataques de Drake a La Habana y a Santo Domingo en 1586 están extensamente reseñados en las historiografías cubana y dominicana. Víctor San Juan incluye el ataque a Puerto Rico de 1595 dentro de una tercera y última fase de agresiones inglesas contra España y sus posesiones ${ }^{73}$.

${ }^{66}$ Carta de Antonio de Berrio, gobernador de Trinidad, 12 de julio de 1595, AGI, SD 179, r. 1, n. ${ }^{\circ} 4$, fs. $1-1 \mathrm{v}$.

${ }^{67}$ Carta de Lope de Vega Portocarrero, presidente de la Audiencia de Santo Domingo, 22 de octubre de 1595, AGI, SD 51, r. 17, n. ${ }^{\circ} 139$, f. 3v.

${ }^{68}$ Carta de Diego de Acuña, gobernador de Cartagena, 30 de noviembre de 1617, AGI, SF 38, r. 5, n. $^{\circ} 145$.

${ }^{69}$ Carta de Juan de Haro, gobernador de Cumaná, 20 de junio de 1618, AGI, SD 187, r. 5, n. $^{\circ} 33$.

${ }^{70} \mathrm{https} / / /$ www.britannica.com/biography/Walter-Raleigh-English-explorer, capturado el 25 de noviembre de 2017.

71 Cardelús y Fernández Toraño, 2013: 210-222.

${ }^{72}$ Hakluyt, 1890: 221-222.

73 San Juan, 2017: 353. La primera fase, que califica como «afrentas», cubre de 1568 a 1587; la segunda, con hostilidades declaradas, va de 1588, con el desastre de la mal llamada Armada Invencible, hasta 1595. 
El gobernador de Cartagena notificó a la corte en 1591 que se había enterado que Draque armaba en Inglaterra una armada de 20 navíos gruesos para Indias $^{74}$, pero no fue hasta finales de 1595 que se concretó su ataque. Las noticias de que la armada inglesa iba sobre ella fueron recibidas en Puerto Rico en junio ${ }^{75}$. La intención era tomar el tesoro en plata que llevaba la Flota de Indias del general Sancho Pardo de Osorio, que ese año había encontrado un huracán, obligándose a entrar de arribada a San Juan el 9 de abril ${ }^{76}$. Por fortuna, cuando el número regular de soldados en la Isla era de 209, en ese momento había $620^{77}$.

La armada inglesa había salido los días 27 y 28 de agosto desde Plymouth con 26 naos $^{78}$. A mediados de noviembre, Pardo anticipó al presidente de la Audiencia de Santo Domingo los planes de los ingleses: pasar diez días en Puerto Rico y de ahí seguir a Cartagena. Pronosticó: «aquí no creo que nos hará mucho daño, que estamos de buen ánimo»; tres días después, Vega Portocarrero lo informó al gobernador de Cartagena ${ }^{79}$. Providencialmente, Pedro Tello de Guzmán había llegado el 13 de noviembre con cinco fragatas a recoger la plata que Pardo había dejado en la Isla. Con los hombres de Tello de Guzmán se hicieron preparativos para la defensa ante el inminente ataque de Drake y Juan de Aquines (John Hawkins), que se encontraban en la isla Guadalupe ${ }^{80}$.

${ }^{74}$ Carta de Pedro de Lodeña, gobernador de Cartagena, 20 de enero de 1591, AGI, SF 37, r. 6, n. ${ }^{\circ}$ 99. Carta de Pedro de Lodeña, gobernador de Cartagena, 6 de septiembre de 1591, AGI, SF 37, r. 6, n. ${ }^{\circ} 102$.

${ }^{75}$ Carta del gobernador Pedro Suárez Coronel, gobernador de Puerto Rico, 8 de junio de 1595, AGI, SD 155, r. 12, n. ${ }^{\circ} 141$.

${ }^{76}$ San Juan, 2017: 335.

77 Carta de Pedro Suárez Coronel, gobernador de Puerto Rico, 19 de diciembre de 1595, AGI, SD 155, r. 12, n. ${ }^{\circ}$ 148. Se desembarcó la gente de las fragatas, 240 hombres, y 70 de Sancho Pardo, y 186 de la compañía de Francisco Gómez Cid, entre ellos 10 artilleros y los de primera plana que serían 17 y 140 de la tierra, para un total de 620 soldados, que se repartieron en los puestos necesarios.

78 «Testimonio del inglés Jorge Tesan», Carta de Pedro de Acuña, gobernador de Cartagena, 12 de febrero de 1596, AGI, SF 37, r. 7, n. ${ }^{\circ} 153$, f. 1.

79 «Copia de una carta que el Presidente de Santo Domingo, Lope de Vega Portocarrero, escribió a don Pedro de Acuña, gobernador de Cartagena, en 19 de noviembre de 1595», Carta de Pedro de Acuña, gobernador de Cartagena, 11 de diciembre de 1595, AGI, SF 37, r. 7, n. ${ }^{\circ} 145$.

${ }_{80}$ Carta de Pedro Suárez Coronel, gobernador de Puerto Rico, 8 de junio de 1595, AGI, SD 155, r. 12, n. ${ }^{\circ}$ 148. Hawkins es merecedor de un estudio para sí solo, pero sus agresiones comenzaron antes, con ataques en 1565 a isla Margarita y Cumaná, entre otras provincias, y murió en el ataque que reseñamos. Arráiz Lucca, 2013: 81-82. 


\section{Puerto Rico}

Finalmente, al amanecer del 22 de noviembre, se avistó el enemigo. Con el disparo de dos piezas de artillería se avisó a la gente de la tierra a recogerse. Drake llegó a la playa de Cabrón con toda su armada antes de mediodía para echar gente en tierra. Se les tiró artillería, que, tras unos ajustes, alcanzaron los navíos grandes. Al anochecer hicieron otro disparo a la capitana que dio por la popa, matando a Hawkins y a dos caballeros que acompañaban a Drake en la mesa donde cenaban.

A la mañana siguiente, en una movida audaz, el inglés envió 27 lanchas sondeando toda la costa, llegando hasta la isleta de San Juan, «frontero del Morro, a más de tiro de cañón, donde nunca se han visto surgir navíos jamás, y fue grande obra la que se hizo en cerrar el cañuelo porque si entraran por él, de ninguna manera les podía ofender la artillería». Tello fortificó la isleta con 30 hombres y 50 arcabuceros y mosqueteros, y armó dos barcos para defender el cañuelo. Esa noche, el enemigo cargó las lanchas y barcos con más de 60 soldados en cada uno. Estando debajo de la artillería, donde no les podía alcanzar, entraron por el puerto, mientras se les disparaban desde las plataformas altas y bajas y desde el Caballero de Austria, lo que sí les hizo mucho daño.

Los españoles siguieron atacando con lo que tenían: arcabuces, mosquetes, y hasta piedras. Los enemigos echaron fuego a la almiranta y a La Magdalena, que fue apagado con mantas mojadas. Uno de los navíos a los que prendieron fuego no se pudo salvar porque «se quemó en un Credo», pero, para beneficio de los españoles, se iluminó todo el puerto, permitiéndoles ver las lanchas enemigas. Les tiraron con arcabucería, mosquetería y artillería, echando a fondo ocho o nueve lanchas. Los enemigos se retiraron, tomando dos marineros y un contramaestre de esta fragata.

Tras dejar la isleta, Drake regresó, pretendiendo entrar al puerto. Se acordó hundir la capitana de las fragatas y los navíos de dos vecinos para impedirles el paso. Cuando el enemigo reconoció que no sería posible entrar, se detuvo por dos días, hasta el 25 de noviembre, cuando finalmente dejó San Juan y llegó al puerto Aguada, en la costa occidental. Allí entraron a una estancia donde prendieron un negro y un indio, y tomaron varios animales. Dejaron a los hombres que habían tomado de la fragata, entregándoles Drake una carta para el gobernador, en la que advertía se tratara bien a los hombres que se le capturaron, o tomaría represalias ${ }^{81}$.

${ }^{81}$ Carta de Pedro Suárez Coronel, gobernador de Puerto Rico, 19 de diciembre de 1595, AGI, SD 155, r. 12, n. $^{\circ} 148$, fs. $1-2$ v. 
En el caso de Puerto Rico, con la ayuda de la Fortuna, se requirió de la combinación de los generales de la flota de Tierra Firme y de los galeones de Nueva España para repeler a Drake.

\section{Río de la Hacha y Santa Marta}

El día 11 de diciembre el gobernador de Cartagena compartió noticias recibidas del general de la flota de Tierra Firme a través del presidente de Santo Domingo: Drake y Hawkins — que había muerto en Puerto Rico, pero se desconocía - se dirigían hacia Cartagena con 25 naos y seis galeones de la reina de Inglaterra ${ }^{82}$. El 19 de diciembre, el gobernador de Cuba escribió sobre la captura de barcos ingleses. Uno de los prisioneros, ignorando el destino de éstos en Puerto Rico, contó que venían 26 navíos a cargo de Drake y Hawkins con 6.000 hombres para tomar Puerto Rico y el dinero que allí había, y luego pasar a Santo Domingo y a Tierra Firme. Maldonado destacó estar preparado para recibir al inglés con una cadena de navíos, asidos unos a otros con cables gruesos llenos de fajina y brea ${ }^{83}$.

A principios de enero de 1596, el gobernador de Cartagena volvió a escribir, sobre las cartas del de Santa Marta contando la llegada inminente de Drake. Desde Santa Marta, Francisco Manso de Contreras escribirá al menos en tres ocasiones - 17, 22 y 24 de diciembre - informando sobre la ocupación y quema de la ciudad por parte del inglés, y las exigencias inglesas de rescates para no hacerlo ${ }^{84}$. En la mañana del 17 de diciembre de 1595, se avistaron 20 velas enemigas en la granjería de las perlas de Río de La Hacha. A las 8 de la noche surgió toda la armada de Drake con 54 velas - un considerable aumento sobre las que llevó a Puerto Rico - incluyendo 30 gruesas, de 200 a 500 toneladas, y las restantes, bajeles pequeños. Echó 2.000 hombres en tierra, que repartió por diferentes caminos.

Con solo 100 hombres, 15 con mosquetes y los demás «con armas muy flacas», el gobernador lo resistió al principio, retrasando que echara gente en la boca del río o en el puerto. Drake desembarcó en la playa por barlovento y sotavento, que eran más de ocho leguas, con los caminos y la tierra llanos.

${ }^{82}$ Carta de Pedro de Acuña, gobernador de Cartagena, 11 de diciembre de 1595, AGI, SF 37, r. 7, n. $^{\circ} 145$.

${ }_{83}$ Carta de Juan Maldonado Barnuevo, gobernador de La Habana, 19 de diciembre de 1595, AGI, SD 99, r. 20, n. 190.

${ }^{84}$ Carta de Pedro de Acuña, gobernador de Cartagena, 3 de enero de 1596, AGI, SF 37, r. 7, n. $^{\circ} 149$. 
Tomó el pueblo, de donde se retiraron los españoles. Según Manso, la meta de Drake era tomar la caja real y a él, «que sin lo uno y otro, aunque se pierdan las armadas y estados de Inglaterra, no se ha de salir del puerto». A pesar de tratar de negociar con el inglés, éste solo quería el tesoro del rey, y al gobernador. A diario se pasaba más gente al bando inglés, incluyendo negros, informándole a Drake todo lo que quisiera saber, y sirviéndole de guía. Sobre ellos, el gobernador escribirá meses después que «se le han huido y van la vuelta del Perú y Nueva España y otras partes» ${ }^{85}$. Como agravante, los españoles se encontraban en guerra con los indios, lo que imposibilitaba obtener de ellos bastimentos o socorros.

Mientras el gobernador de Cartagena había pedido que se le quitaran las piezas de bronce dadas a Santa Marta, Manso pagó el precio de permitirle a Drake que quemara su ciudad para dar tiempo a Cartagena, Portobelo y Nombre de Dios a reforzar para sus defensas. El 17 de diciembre advertía a Cartagena: «... por muchas partes le ha de echar gente y a boca de noche y con lo oscuro, pero si se le muestra[n] dientes éstos tienen pocos y ha sucedido, en viendo diez hombres de a caballo, retirarse un grande escuadrón» ${ }^{86}$.

Repitiendo la estrategia utilizada en Santo Domingo años antes, pidiendo recompensas para abandonar las ciudades, Drake las pidió para liberar al teniente don Francisco Gutiérrez Flores. Luego de robar y quemar la ciudad con más de mil hombres, se hizo a la vela, para dirigirse a Nombre de Dios ${ }^{87}$. Finalmente abandonó Santa Marta el 29 de diciembre de $1596^{88}$.

\section{Panamá}

La inteligencia imperial española tuvo resultados favorables en esta ocasión. Salazar reportó que, desde Puerto Rico, se dio aviso al presidente de Santo Domingo sobre la llegada de la armada enemiga, viendo algunos navíos

${ }^{85}$ Carta de Francisco Manso de Contreras, gobernador de Santa Marta, 24 de marzo de 1596, AGI, SF 49, r. 17, n. ${ }^{\circ} 120$.

86 "Copia de una carta que el gobernador de Santa Marta escribió a don Pedro de Acuña en 17 de diciembre de 1595", Carta de Pedro de Acuña, gobernador de Cartagena, al rey, 3 de enero de 1596, AGI, SF 37, r. 7, n. ${ }^{\circ} 149$.

${ }^{87}$ Carta de Pedro de Acuña, gobernador de Cartagena, 5 de enero de 1596, AGI, SF 37, r. 7, n. $^{\circ} 151$.

88 «Información sobre los avisos que se enviaron a Cartagena en el tiempo que estuvo en este puerto el armada inglesa y de su detenimiento mediante las trazas y medios del gobernador», Carta de Francisco Manso de Contreras, gobernador de Santa Marta, 24 de marzo de 1596, AGI, SF 49, r. 17, n. ${ }^{\circ} 120$, f. 1. 
suyos en la isla Guadalupe; el gobernador de Cartagena también reportó que una fragata que venía de la Laguna de Maracaibo había avistado la armada en el Cabo de la Vela, y los vio ir sobre Río de La Hacha el 11 de diciembre. Sotomayor envió 72 hombres a Nombre de Dios y 100 al Río de Chagre, 62 a Portobelo. Se mandó hacer una fortificación en Las Lomas de Capirida, renombrado San Pablo de la Victoria.

Cuando se entendió que Drake iba sobre la ciudad de Panamá, la ciudad de Natá envió socorro de españoles, con 30 vecinos y naturales del pueblo de Penonomé (indios). Con un limitante desbalance de fuerzas, decenas de españoles ante centenares de enemigos, estuvieron 20 días ayudando en la construcción de un fuerte, de lo que enfermaron y murieron muchos ${ }^{89}$.

En la mañana del día de Reyes, el enemigo entró en Nombre de Dios con 40 velas. Se supo que se retiraba a Capira, guiado por negros. Carecía de comida y municiones, y los soldados, fatigados de hambre y aguaceros, iban descalzos. Por instrucciones de la Audiencia, los vecinos de Natá, Veragua y Los Santos habían abandonado los pueblos, internándose en la montaña. Se despachó al capitán Fernando de Liermo Agüero, persona a cargo del presidio de Bayano, con 30 soldados de Los Santos y 10 de su cargo, con bastimentos y municiones para socorrer al alcalde mayor.

Los españoles tuvieron tiempo suficiente para fortificarse. En la mañana del miércoles, 10 de enero, llegó el enemigo al fuerte con entre 600 y 900 hombres. Cuando llegó el refuerzo de Agüero, el enemigo se retiró: «halláronse muchos muertos desde allí a la Venta de la Quebrada, y después se hallaron más hasta Capira, porque los heridos fueron muchos, y con el largo y mal camino y ríos y aguaceros y falta de comida, se iban quedando». Informados por ingleses apresados de que la intención de Drake era tomar la ciudad de Panamá para subir por el Río de Chagre, se mandó fortificar el Río y recoger la gente a la casa de Cruces.

El lunes, 15 de enero, el enemigo se hizo a la vela, presuntamente en busca de bastimentos. Se sospechaba que iría a Portobelo; Drake llevaba consigo un arquitecto y un negro, y buscaba un piloto para aquel puerto. Todavía el sábado 20 el enemigo no se había presentado en Portobelo ni en Río de Chagre, por lo que se entendía había regresado a Inglaterra; de haberlo intentado, «con brisa en popa, lo hubiera logrado ese mismo día, cuando se hizo a la vela $\rangle^{90}$. El licenciado Salazar reportó que Drake salió de Portobelo el 18 de febrero, a donde se había mudado la población de Nombre de Dios tras ser incendiada por el inglés. Se esperaba que Drake regresara en un par

\footnotetext{
${ }^{89}$ Carta de la Audiencia de Panamá, 11 de julio de 1618, AGI, PAN 17, r. 2, n. ${ }^{\circ} 17$.

${ }^{90}$ Carta del oidor Salazar, 22 de enero de 1596, AGI, PAN 14, r. 12, n. ${ }^{\circ} 68$, fs. $1-2$ v.
} 
de meses a la costa de Tierra Firme. En esta carta se reporta que el general don Bernardino de Avellaneda avistó la flota de Drake, pero que, por estar tomando agua, no lo pudo perseguir ${ }^{91}$. Drake moriría posteriormente a consecuencia de las heridas de estas batallas.

Los prisioneros que se le tomaron confirmaron que Drake habría seguido su viaje a Inglaterra porque había echado en tierra toda la gente inútil; sólo se quedó con los prisioneros de rescate; de los negros, quedó con los buzos de Río de La Hacha. Según señalaron,

La enemiga vuelve con gran menoscabo y destrozada con muchos navíos y gente principal al menos porque de 27 navíos que sacó de Inglaterra, sacó solos 18 de Portobelo, que los nueve ha dejado y perdido en esta manera:

- Las fragatas de España le tomaron uno---------------------------------- 1

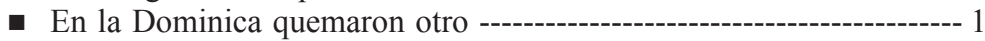

- En Guadalupe quemaron otro ----------------------------------------- 1

- Otro se le perdió de Puerto Rico al Río de La Hacha ---------------- 1

- En el escudo de Veragua quemó otro -------------------------------- 1

- Dos echó a fondo en el Río de La Hacha -------------------------- 2

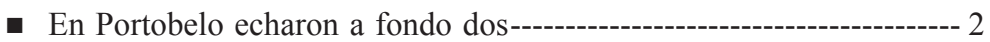

- Éstos además del patache del capitán Melchor Suárez que tomó en el escudo de Veragua, que también echó a fondo en el dicho Portobelo.

- La armada debió de sacar de Inglaterra 3.000 hombres de guerra y mar, aunque publicaban y echaban fama de 5.000, y ahora no lleva 2.000, porque le han muerto en Puerto Rico y Tierra Firme y de enfermedades más de 1.000, y entre ellos muchas cabezas y personajes conocidos de calidad y gran reputación, especialmente.

- Dos generales que son Juan Aquines y Francisco Drach, corsarios famosos, tan conocidos y que han intentado y hecho cosas tan famosas, mayormente el Francisco Drach, del cual se debe notar que desde primero comenzó como corsario fue en este reino en cuya costa y en la misma tierra hizo diferentes robos y las había porque las anduvo disimulado y estuvo en Panamá y quiso Nuestro Señor que acabase en ella ${ }^{92}$.

El caso de Drake demuestra la efectividad de las comunicaciones desde la metrópoli, y entre las colonias mismas, sobre las incursiones inglesas sobre su imperio. Aunque parecían abandonadas a su suerte, las colonias recibían inteligencia desde la Corte y desde las gobernaciones vecinas para que se prepararan dentro de las limitaciones que la falta de artillería, municiones, pólvora o soldados les presentaban. Igualmente, quizás porque defendían lo suyo, unos pocos soldados pudieron repeler los ataques de fuerzas superiores en número.

${ }^{91}$ Carta del oidor Salazar, 25 de mayo de 1596, AGI, PAN 14, r. 12, n. ${ }^{\circ} 73$, fs. 1-2.

${ }_{92}$ Carta del oidor Salazar, 22 de enero de 1596, AGI, PAN 14, r. 12, n. ${ }^{\circ} 68$, fs. $1-2 \mathrm{v}$. 
George Clifford, Conde de Cumberland, 1598, Puerto Rico

En 1596 el gobernador de Cartagena refería haber recibido noticias de la Casa de la Contratación en Sevilla sobre la salida del «Conde Comberlan», o «Comorlan», con una armada para Indias. En anticipación a la agresión inglesa, el gobernador solicitaba que se le enviaran 300 arcabuces, 50 mosquetes, 300 picas, 50 quintales de pólvora, culebrinas, piezas pedreras y 150 o 200 soldados de Castilla, además de 200 remeros forzados y esclavos para las galeras ${ }^{93}$. En octubre de 1598 reconoció haber recibido la carta sobre el avistamiento de Cumberland sobre Lagos, y solicitó nuevamente armas y pólvora ${ }^{94}$.

El 11 de agosto de 1598 se recibió del gobernador de Jamaica una carta donde le informaba que al puerto habían entrado tres navíos ingleses con el gobernador de Puerto Rico y otras 300 personas, entre soldados, vecinos y mujeres: Puerto Rico se había perdido al inglés. Incluyó dos relaciones sobre lo sucedido que se tomaron a dos personas que se encontraban en ellos: uno era un marino que fue tomado en el Cabo San Vicente ${ }^{95}$ y otro, Francisco Delgado, había sido sargento mayor y teniente de gobernador de Puerto Rico ${ }^{96}$.

Según relató un testigo, el 12 de abril de 1598 un patache que salía de Lisboa a Sanlúcar se encontró con una armada inglesa en el Cabo de San Vicente con 22 velas, compuesta por ocho navíos de 350 a 500 toneladas, y las demás de menor tonelaje, en dos escuadras. Fueron tomados por dos lanchas grandes de remos, y lo llevaron a donde el Conde de Cumberland. El testigo declaró que la información la obtuvo de un inglés católico que había sido soldado aventajado en las galeras de España, y le contaba todo según se iba sucediendo.

Se informó que iban a Puerto Rico, un viaje que tomaba dos días. El martes, 14 de junio, amaneció sobre la ciudad la armada enemiga, echando en tierra alrededor de 600 hombres con 7 banderas en la playa de Cangrejos, a cuatro leguas de la ciudad. El Conde, su almirante, mosqueteros, arcabuceros y piqueros bajaron a tierra. Tres negros de la tierra les enseñaron el camino para llegar al puente de Aguilar, que unía la isleta de San Juan con la isla principal, que alcanzaron el 14 de junio. Los ingleses embistieron desde esa

${ }^{33}$ Carta de Pedro de Acuña, gobernador de Cartagena, 5 de septiembre de 1596, AGI, SF 37, r. 7, n. ${ }^{\circ} 161$, fs. 1-1v.

${ }^{94}$ Carta de Pedro de Acuña, gobernador de Cartagena, 22 de octubre de 1598, AGI, SF 38, r. 1, n. ${ }^{\circ} 13$, f. $1 \mathrm{~V}$.

${ }_{95}$ Carta de Pedro de Acuña, gobernador de Cartagena, 11 de agosto de 1598, AGI, SF 38 , r. 1 n. $^{\circ} 6$.

${ }^{96}$ Información de Juan de Melgarejo, 1582, AGI, SD 14, n. ${ }^{\circ} 10$, fs-30v-34. 
noche hasta el día siguiente, pero no pudieron ganar la batalla, y se retiraron tras perder entre 50 y 60 hombres, habiendo herido como a 24 españoles. En el puente se encontraron al capitán Sierralta, que los resistió, les mató 60 hombres, y destruyó el puente ${ }^{97}$.

Cumberland ganó finalmente el puente y tomó la artillería. Alrededor de 180 hombres salieron en lanchas y se apoderaron del boquerón. Siguieron marchando a la ciudad, sin enfrentar resistencia. Contrario a lo que sucedió a Drake en Panamá, en la ciudad encontró mucha carne, vino y refresco. Trescientos soldados se habían retirado con el gobernador Mosquera, el exgobernador Suárez Coronel, los capitanes de infantería y otros vecinos al Morro. Los ingleses iban tan cansados, que con 50 soldados los hubieran eliminado ${ }^{98}$; sin embargo, algunos soldados, y hasta vecinos, se pasaron al enemigo ${ }^{99}$. En la mañana del jueves 16 , el enemigo tomó la ciudad con su gente, banderas y tambores. Se atrincheraron en las calles principales, «dejando las casas de la trinchera adentro», saliendo hacia el morro con más trincheras. Plantaron artillería tomada a los españoles y sacada de sus navíos, con la cual «nos batió con grandiosa consideración tiempo de 14 o 15 días» ${ }^{100}$.

El Conde envió mensaje al gobernador para que se rindiera, el cual fue rechazado. Entonces se atrincheró frente al convento de Santo Domingo, «a tiro de mosquete del Morro». Los españoles atacaron, pero, al no sostener el ataque, los ingleses pudieron atrincherarse con ocho piezas, cuatro de bronce y cuatro de hierro colado que sacó de la capitana. En un golpe de suerte, en contraste con la escasez reportada en la correspondencia española, Cumberland encontró 200 barriles de pólvora en la ciudad, y balas y carretones, los cuales utilizó durante dos días sin gastar la suya. Dentro del Morro hallaría más adelante 30 carretas con sus bueyes, muchas pipas de vino y una fragata llena de harinas.

97 «Relación de los sucedido a la Armada del Conde Combarlan desde que pareció en el Cabo de San Vicente hasta que tomó a Puerto Rico y la Fortaleza del Morro, dada por un soldado que se llama García de Valdés, que tomó en el dicho Cabo en un patache y lo trajeron hasta el dicho Puerto Rico, de donde lo enviaron con la demás gente a la isla de Jamaica, y de ella vino a esta ciudad de Cartagena con aviso del suceso», Carta de Pedro de Acuña, gobernador de Cartagena, 11 de agosto 1598 , AGI, SF 38, r. 1, n. ${ }^{\circ} 6$. fs. 1-2v.

98 Idem.

99 «Relación de lo sucedido en la ciudad de Puerto Rico y toma de ella por el Conde Comorlan, inglés, y de lo demás sucedido, según la relación que da Francisco Delgado, vecino de la dicha isla de Puerto Rico, y de otras muchas personas, es la siguiente», Carta de Pedro de Acuña, gobernador de Cartagena, 11 de agosto de 1598, AGI, SF 38, r. 1, n. ${ }^{\circ} 6$, f. 1.

100 Idem. 
Cumpliendo su promesa ${ }^{101}$, el Conde mandó alistar tres navíos, acompañados de dos barcos de su armada, para enviar al gobernador, a sus soldados y a la gente fuera de Puerto Rico, quedándose con Suárez Coronel para llevarlo a Inglaterra. Finalmente, dejó algunas personas en Cabo de Tiburón y a otras las llevó hasta Jamaica, sobre la que tenía intención de caer en 15 días. Dejaría en Puerto Rico seis navíos y 500 soldados en la fuerza. Pasaría a la isla Tercera a aguardar los barcos que venían de la India, y regresaría a la reina. Entre los ingleses se especulaba que la reina mandaría a fortalecer la isla, por lo que enviarían por sus mujeres. Otros pensaban que viajarían a Cartagena ${ }^{102}$.

Eventualmente, Cumberland abandonaría la isla de Puerto Rico. Una epidemia de disentería que había afectado a la población local antes de su llegada se propagó entre sus tropas. Se abandonaron así los planes de establecer una colonia para la reina Isabel, no sin antes apoderarse de los productos de la tierra que encontró, llevándose hasta las campanas de la iglesia y los ornamentos del convento de los dominicos. Sólo el situado se salvó, que fue llevado a las montañas durante la ocupación ${ }^{103}$. Salió de Puerto Rico el 14 de agosto de $1598^{104}$.

\section{Anthony Sherley, 1597, Santa Marta, Jamaica, Honduras}

Sir Anthony Sherley, más conocido por sus viajes a Oriente que al Caribe, se encuentra entre los caballeros ingleses convertidos en capitanes del mar embarcados en los ataques a las posesiones españolas. Hakluyt lo identifica como corsario financiado parcialmente por la reina Isabe ${ }^{105}$. Aunque su intención inicial era llegar a la isla de San Tomé, en 1596 arribó a la de Santiago,

${ }^{101}$ Idem. Para Delgado, la razón para la rendición fue el temor de que los soldados españoles que se pasaron al enemigo, incluyendo un lombardero, hubiesen dado relación de la flaqueza del Morro.

102 «Relación de los sucedido a la Armada del Conde Combarlan desde que pareció en el Cabo de San Vicente hasta que tomó a Puerto Rico y la Fortaleza del Morro, dada por un soldado que se llama García de Valdés, que tomó en el dicho Cabo en un patache y lo trajeron hasta el dicho Puerto Rico, de donde lo enviaron con la demás gente a la isla de Jamaica, y de ella vino a esta ciudad de Cartagena con aviso del suceso», Carta de Pedro de Acuña, gobernador de Cartagena, 11 de agosto de 1598, AGI, SF 38, r. 1, n. ${ }^{\circ}$ 6. f. 2.

${ }_{103}$ Carta de Alonso de Mercado, gobernador de Puerto Rico, 5 de mayo de 1599, AGI, SD 155 , r. 14, n. $^{\circ} 156$.

104 Morales Carrión, 2003: 48-49.

${ }^{105}$ Citado en Kristzler, 2008: 164. 
de donde pasó a Dominica y a isla Margarita ${ }^{106}$. Viajó a Tierra Firme junto a William Parker. Estuvo en Santa Marta hasta enero de 1597, cuando salió para Jamaica, donde estuvo hasta el mes de marzo. Durante dos semanas ocupó La Vega, saqueando los campos ${ }^{107}$. De ahí procedieron a Honduras, donde se unieron a Parker ${ }^{108}$. Atacó pueblos en Nueva España, donde fue herido luego de un ataque en el que utilizó a sus prisioneros como barricada humana contra la embestida de los vecinos, y regresó a Inglaterra en julio de $1597^{109}$.

En junio de 1597 el gobernador de Santa Marta hizo referencia a la información enviada a España sobre la llegada en enero de "Antonio Shorleyo», inglés. Llegó a Tierra Firme con cinco navíos y varios pataches con 600 hombres y ocuparon la tierra por más de 20 días. Aunque superados en número, los españoles se le enfrentaron. Los ingleses lograron tomar el pueblo, pero fueron obligados a dejarla con poco daño a los edificios de importancia. Durante seis meses, se vivió en gran tensión, llamando a rebatos a los vecinos. El gobernador Manso asociaba estas agresiones con la derrota a Drake, añadiendo «es tanto el odio que han cobrado que no sale corsario de su tierra que no sea con ánimo de probar la mano en ésta y en venganza del daño recibido, destruirla» ${ }^{110}$.

John Watts, 1597, Santa Marta y Río de La Hacha

El gobernador Manso de Contreras también informó de otros dos navíos corsarios y dos lanchas que en marzo de 1597 tomaron las canoas y los negros de las pesquerías. Robaron la jarcia y las velas a las canoas; les tomó dos meses volver a la pesquería. En junio pasó la armada a cargo del general Garibay, por lo que el inglés se escondió, regresando a Santa Marta, sin poder hacer daño. Volvió a las pesquerías, donde fue atacado por 30 soldados españoles apostados para su defensa. Allí estuvo lombardeando sobre dos horas.

A la medianoche del 3 de julio los ingleses se presentaron en la ranchería con seis navíos «de mucha fuerza» con pataches y lanchas y echaron en tierra sobre 400 hombres. Nuevamente, el día 7, el inglés bajó al puerto con catorce velas, siendo enfrentados por el gobernador Manso y sus 60 hombres armados de mosquetes y arcabuces, pero con pocas municiones, tan poca, «que

106 Hakluyt, 1890: sin número de página.

107 Kristzler, 2008: 164.

108 Pinto Soria, 1993. En esta obra de Pinto Soria no hay referencia a este ataque.

109 Southey, 1827: 215-216.

110 Carta de Francisco Manso de Contreras, gobernador de Santa Marta, 19 de junio de 1597, AGI, SF 49, r. 17, n. ${ }^{\circ}$ 122, f. 1-2. 
no había una arroba de pólvora». Finalmente, enviaron una barca con una bandera de paz y un mensaje al gobernador donde le solicitaban tomar agua en el río, luego de lo cual partirían sin más molestias para el pueblo.

Manso de Contreras se negó a darles acceso a agua. Saltaron a tierra con 400 hombres, pero encontraron la resistencia de los españoles, quienes hicieron parecer que eran muchos más. Luego de varios intentos, enviando solicitudes, siendo la respuesta la misma siempre, el inglés se hizo a la vela el 11 de julio. El general inglés fue identificado como Juan de Guatre, hijo del gobernador de Londres, «mozo de hasta 20 años». Se entendía que su plan era llegar al cabo San Antón para aguardar la armada española, «que saben trae muy pocos de fuerza, y dicen que, para cada uno, tienen ellos tres ${ }^{111}$.

William Parker, 1600, Portobelo

A finales de 1600, el gobernador de Cartagena reportó el saqueo del inglés Guillermo Parque a Portobelo. No se supo el nombre de su almirante o de sus dos capitanes ingleses. En cada uno de sus dos navíos traía 140 hombres; estas naves no eran armadas por la reina, sino por el propio general ${ }^{112}$. El monto tomado no pasó de 20.000 pesos, pero quedaba el riesgo de que robara las barras de oro que se recibían en la ciudad de Panamá.

Acuña resumió el ataque del 16 de febrero de 1601 informando que los ingleses llevaron dos navíos, uno de 100 y otro de 60 o 70 toneladas, con 160 personas; embarcó 90 hombres en lanchas y llegó hasta el fuerte. Allí les permitieron entrada, al contestar que eran de Cartagena y llevaban bastimento. Como los soldados dormían descuidados, estuvieron saqueando el pueblo y dos fragatas en el puerto durante el día, escapando con facilidad de noche, sin perder un solo hombre. Un comentario pesimista resume la pobre preparación de las colonias para enfrentar estos ataques: «si no se remedia aquello, cada día podrá suceder lo mismo, y para mí no ha sido mucha novedad, que días ha que lo tenía contevisto [sic, ¿anticipado?] de la misma manera que sucedió, y aún lo dije muchas veces desde el día que vi la planta» ${ }^{113}$.

El proceso contra los soldados considerados responsables no se hizo esperar. Según declaró Pedro de Soto, a las tres de la mañana del 17 de febrero

\footnotetext{
111 Ibidem, fs. 2-3. Su padre se llamaba igual, John Watts, comerciante y dueño de barcos.

112 «Autos y averiguaciones hechas por el señor don Alonso de Sotomayor...», Carta de la Audiencia de Panamá, 23 de julio de 1601, AGI, PAN 15, r. 2, n. ${ }^{\circ} 11$, fs. 10-10v.

113 Carta de Pedro de Acuña, gobernador de Cartagena, 24 de diciembre de 1600, AGI, SF 38, r. 1, n. $^{\circ} 29$, fs. $1-1$ v.
} 
se oyeron arcabuzazos en la ciudad, que resultaron ser de enemigos. Fue informado que habían entrado dos lanchas o fragatas en la Punta del Manglar, sin que se hubiese tirado disparo alguno contra ellas. Después de que los vecinos dieron voces, del castillo se disparó un mosquete. El enemigo llegó a la ciudad a través de la banda de la ranchería de perlas y el fuerte de Santiago. No tiraron al enemigo porque no se ordenó hacerlo ${ }^{114}$.

El sábado por la mañana los ingleses saquearon la ciudad, llevando «mucha ropa, dineros, plata labrada y otras muchas cosas, jabón, harina y vino». Añadió que llevaron todo el dinero y la plata que había en las dos cajas reales tras destrozarlas con hachas. Esa noche, el inglés se hizo a la vela. Pasó a una fragata que habían tomado, y allí su general, Parker, fue herido de un mosquetazo en el brazo derecho. A pesar de esto, ninguna de la artillería que les tiraron a las lanchas acertó a hacer daño. Esa noche el enemigo anduvo barloventeando, y amaneció en las minas, desde donde mandaron a buscar sus naos, que llegaron el domingo en la mañana.

Entre las cosas que embarcaron se encontraban tres piezas de artillería de bronce pequeñas tomadas en el puerto y dos de una fragata. El general inglés intentó rescatar esta fragata, al factor Diego de Ortega Funes, y a 14 negros del rey y de particulares que había tomado; finalmente, se hizo por 500 pesos la fragata, 500 por el factor, y 1.000 pesos por los negros ${ }^{115}$. El general inglés fue identificado como «Guillermo de Porques», el mismo enemigo que tomó a Tolú y la ranchería de La Margarita, y el año anterior tomó Campeche, y también había tomado a Honduras. Sobre él, el testigo Juan Vicente dijo que «es hombre muy bien afortunado en tierra y desgraciado por la mar, de que él se queja».

Revelando la participación de españoles en la tripulación del inglés, el testigo Nicolás Espinola declaró que entre los hombres que acompañaron al general Guillermo había un marinero de la flota de Sancho Pardo Osorio que hablaba muy buen español, y otros hombres muy «españolados». Los testimonios de otros individuos narran los sucesos luego que el enemigo salió de la ciudad y siguió en barco por la costa, robando. En las declaraciones de los testigos de la toma de la fragata de Domingo de Licona se menciona la presencia de portugueses y vizcaínos que habían sido tomados también por los ingleses ${ }^{116}$.

En 1601 el gobernador de Cumaná reportará que obtuvo inteligencia a través de un flamenco que, un ataque español le había muerto a Parker algu-

114 «Autos y averiguaciones hechas por el señor don Alonso de Sotomayor...», Carta de la Audiencia de Panamá, 23 de julio de 1601. AGI, PAN 15, r. 2, n. ${ }^{\circ} 11$, fs. 9-12.

115 Ibidem, f. 9v.

116 Ibidem, fs. 10v-12. 
na gente y llevaba muchos heridos. ${ }^{117}$ Todavía en 1602 se estaban enjuiciando a los soldados acusados por la entrada del inglés a Portobelo ${ }^{118}$.

\section{Capitán Simón Bourman (Boreman), 1601, Cartagena}

El caso de Simón Bourman es interesante por demás, puesto que fue capturado casi tan pronto llegó a Tierra Firme, antes de poder hacer daño a las posesiones españolas. Su valor yace en su aparente conversión al catolicismo, y la inteligencia que compartió con el gobernador de Cartagena. El capitán Bourman fue capturado con toda su gente en el Cabo de la Vela por las galeras de Cartagena en octubre de 1601, a donde llegó el 18 del mes. Llevaba título de capitán de la reina de Inglaterra, con un navío y lancha. Según declaró, había nacido en Sevilla, hijo de Simón Bourman, inglés, y de Isabel Gil de Laysalde, natural de Málaga, y se había criado en la fe católica. A los cinco meses de edad fue llevado a Inglaterra, donde trabajó en servicio del Conde de Essex. Tenía familiares en España, que eran personas principales: el capitán Juan Gil de Laysalde, regidor de Málaga, su tío matero; y doña Cecilia Bourman, casada con don Manuel de Benavides, castellano de Cádiz, como prima hermana ${ }^{119}$.

Probablemente considerando salvarse de la ahorca, abjuró de la herejía luterana, «renunciando la secta en que había sido criado por su ignorancia y malicia de su padre» ${ }^{120}$. Ofreció información al gobernador Zuazo, quien la utilizó para presentar recomendaciones para mejorar las defensas del territorio español. A través de sus recomendaciones, que cubren ocho folios, se revelaban los grandes espacios donde los esfuerzos de seguridad españolas no llegaban, en los cuales los extranjeros campeaban por su respeto.

Entre éstas se encontraba el fortalecimiento de la Punta de Araya para que los enemigos no la pudieran tomar. Declaró que a la banda este de la punta llegaban diariamente muchos navíos flamencos e ingleses a cargar sal, «por

117 Carta de Diego Suárez de Amaya, gobernador de Cumaná, 13 de febrero de 1601, AGI, SD 187, r. 3, n. ${ }^{\circ} 7$, f. 1.

${ }_{118}$ Carta del oidor Alberto de Acuña, 15 de junio de 1602, AGI, PAN 15, r. 3, n. ${ }^{\circ} 20$, f. 1.

119 En el portal de Genealogía www.geni.com, se encuentra la del capitán Hugh Bourman o Boreman, Conde de Leigh. Era hijo de James Boreman y de Isabel Carvanell, y estaba casado con Isabel Gil de Avilés; éstos son los padres del capitán Simón Bourman, https://www.geni. com/people/Simon-Borman/6000000028105125232, capturado el 25 de noviembre de 2017.

120 “Testimonio de cómo el capitán inglés, Simón Bourman, inglés, fue reducido a nuestra santa fe católica", Carta de Jerónimo de Zuazo, gobernador de Cartagena, 1 de agosto de 1603, AGI, SF 38, r. 2, n. ${ }^{\circ} 52$, fs. 1-1v, 4. 
haberlos faltado la que se solía hacer en La Rochela respecto de haberse perdido las salinas, y también por haber cesado el Holanda y Gelanda el trato de España, de donde se solían proveer de ella». Cada navío, de entre 200 a 600 toneladas, no traía más de 30 a 40 hombres.

La segunda recomendación se relacionaba a impedir el rescate de toda la costa de Caracas, Margarita y Cumaná, que, según el inglés, generaba más de millón y medio cada año, e identificar a quienes hacían tratos y contratos en esta costa para castigarlos. En ella retrataba la ruta seguida por los navíos ingleses, tomando agua en las isletas de los Testigos en Margarita, para pasar a reconocer a Santo Domingo ${ }^{121}$. Fue enviado a España para que informase de estas cosas directamente al rey y su Consejo de Indias ${ }^{122}$.

General Cristóbal Nazcur, 1603, Jamaica

Morales Padrón sostiene que las defensas de Jamaica nunca fueron adecuadas, reflejo de la negligencia o descuido que afligió a Jamaica en todos los aspectos bajo el dominio español. Asocia esta realidad con la concesión del marquesado de Jamaica a los Colón, que conllevaba la prohibición de construir fuertes ${ }^{123}$. En 1603 el gobernador de Jamaica escribió al de Cartagena sobre la llegada a aquel puerto de 16 velas inglesas: el general era don Cristóbal L. Nazcur. Su intención era obtener bastimentos; si no se los entregaban, quemarían el pueblo.

Mientras el gobernador lo entretenía para hacer algunas prevenciones, el pueblo, aterrado, abandonó la ciudad, viajando a los hatos; solo quedaron 60 hombres para defender la ciudad de Santiago de la Vega. La mañana siguiente, el inglés salió a tierra y llegó hasta donde se había atrincherado el gobernador con sus hombres. Los españoles «pelearon los pocos como leones», obligando al enemigo a retirarse y embarcarse nuevamente. Según un vaquero español que prendieron los ingleses, «este enemigo va rabiando de hambre» ${ }^{124}$.

121 «Relación que da el capitán Simón Burman, inglés», Carta de Jerónimo de Zuazo, gobernador de Cartagena, 1 de agosto de 1603, AGI, SF 38, r. 2, n. ${ }^{\circ} 52$.

122 Carta de Jerónimo de Zuazo, gobernador de Cartagena, 1 de agosto de 1603, AGI, SF 38, r. 2 , n. ${ }^{\circ} 52$, fs. $1-1 v$.

${ }^{123}$ Morales Padrón, 2003: 129.

124 «Traslado de una carta de don Fernando Melgarejo de Córdoba, gobernador de Jamaica», Carta de Jerónimo de Zuazo, gobernador de Cartagena, 15 de febrero de 1603, AGI, SF 38 , r. 2 , n. ${ }^{\circ} 46$. 
Sin embargo, el enemigo entró a la ciudad y la saqueó. Las consecuencias del ataque no quedaron recogidas en las cartas de los gobernadores, pero sí en las informaciones de algunos vecinos. Ese mismo año de 1603, el abad Francisco Márquez de Villalobos se quejaba de los efectos del ataque inglés en sus caudales. Al llegar a Jamaica había llevado paños de colgar y guadamecíes y camas de seda y mucha cantidad de ropa blanca y vestuario para su persona, libros y criados que le servían y acompañaban. En consecuencia, lo había perdido todo, y había quedado en tanta disminución la isla, que no había posibilidad de reponerlo ${ }^{125}$.

A los ingleses les tomarían otros 50 años cambiar la política de molestar, al Designio Occidental, que conllevaba arrebatar a España sus posesiones, lo que logrará definitivamente con Jamaica en 1655.

Ese año de 1603 fue el último del periodo de guerra abierta entre Inglaterra y España que tuvo como escenario el Caribe. Con la muerte de Isabel ese año, las hostilidades terminaron con la ascensión al trono del rey Jacobo Estuardo. La paz sería sellada con el Tratado de Londres en 1604. Esto no significó, no obstante, que Inglaterra renunciaría a sus intenciones de ocupar territorio en Norte América y en Guyana, algo que España no estaba capacitada para evitar ${ }^{126}$.

\section{CONCLUSIONES}

Enemiga declarada de Felipe II, la reina Isabel I apoyó los planes de sus súbditos para hacer daño a quien hasta entonces había sido dueño del mundo. En Inglaterra, desde hombres nobles hasta mercaderes se habían convertido en generales corsarios para intentar robar a España sus riquezas y territorios. Sus nombres fueron fundidos en la historia del Caribe a fuerza del calor del cañón y de la artillería. Las historias generales, imperiales y nacionales registran las principales agresiones de estos enemigos de España. Sin embargo, la correspondencia de los gobernadores nos ofrece, desde la primera línea de combate, una mirada a la tensión y el constante riesgo en que vivían los vecinos del Caribe desde la perspectiva local de las colonias. Carentes de defensas, pero con el orgullo hispano intacto, consideraban los ataques atrevimientos y osadías.

\footnotetext{
$11 \mathrm{v}, 15 \mathrm{v}$ ${ }^{126}$ Andrews, 1978: 253.
}

${ }^{125}$ Informaciones de Francisco Márquez de Villalobos, 1603, AGI, SD 16, n. ${ }^{\circ}$ 11, fs. 2 , 
La correspondencia de las colonias nos presenta, aunque quizás en un tono exagerado, el valor e ingenio que necesitaron los gobiernos coloniales para defenderse, frente a las limitaciones que les imponía la incapacidad de la metrópoli de proveerlos de los necesario. Sus insistentes ruegos por recursos para defender los territorios españoles no siempre fueron escuchados. El enemigo los superaba en número y armamentos. Conocemos el estado de alerta, que rozaba en la desesperación, en el que se vivían ante los inminentes y continuos ataques ingleses. Parecería que la Corona había abandonado a sus posesiones. El repudio del ataque de Drake en Puerto Rico pudo servir para demostrar la efectividad de la defensa cuando se tenían los recursos adecuados.

La inteligencia de España sobre las salidas de naves inglesas con intención de atacar sus posesiones fue muy buena, según lo evidencian las cartas de los gobernadores. Sin embargo, no fue acompañada de los recursos para poder repeler los ataques que anticipaban. Desde España no llegaban la artillería, las municiones ni los soldados requeridos para conservar el imperio, mientras que desde Inglaterra salían innumerables «velas» para intentar tomarlo. Abandonadas por igual a su suerte, las gobernaciones caribeñas se informaban unas a otras sobre el paso de estos corsarios para darles tiempo de prepararse, a pesar de las limitaciones a las que fueron sometidas. A nivel colonial, la inteligencia imperial probablemente permitió a los gobernadores extender la hegemonía de España en la región por algunas décadas, a pesar de la debilidad militar de la metrópoli.

Hombres de capa y espada, o letrados, los gobernadores españoles tuvieron que enfrentar con ingenio, astucia y una gran medida de suerte el empecinado empuje inglés sobre las Indias. Quizás la fe que pusieron en la divina providencia, que no les correspondió en su ataque a Inglaterra de 1588, les dio resultados cuando se tuvieron que defender. El estado de inquietud es palpable en las cartas. El plan de la reina para incordiar a Felipe II, sumado a las debilitadas defensas para enfrentar el daño del enemigo, daría paso a una escalada en las agresiones inglesas y su establecimiento definitivo en el Caribe unas décadas más tarde, algo que la reina Isabel I no viviría para disfrutar.

Un elemento que es meritorio de estudio futuro se halla en la cantidad de soldados y negros que se pasaron al bando enemigo cuando éste atacaba. Las causas pueden encontrarse en la oferta de libertad que el inglés hizo a los negros en Puerto Rico, y quizás hizo lo propio en Río de la Hacha y Panamá. En el caso de Guyana y Trinidad, las promesas de Raleigh alimentaron los deseos de los indios de poner fin a su servidumbre a los españoles, aunque serían siervos de la reina de Inglaterra. Sin embargo, se desconocen las razones de los desertores españoles que sirvieron de guía y consejeros al enemigo en Tierra Firme y Puerto Rico. 
Mientras Inglaterra se crecía como potencia en los mares, España, apolillada por la bancarrota financiera y moral, perdía su capacidad de retener lo que, por más de un siglo, producto de sangre, fuerza e ingenio, le había pertenecido. Ya fuera para robar, forzar el comercio, o sencillamente para tomar bastimentos y agua, los ingleses parecían poder campear por las colonias caribeñas a su gusto. Su superioridad numérica sobre las fuerzas defensivas españolas, compuestas por algunos soldados del rey y algunos vecinos, fue avasalladora, aunque no siempre triunfante. David Watts opina: «aunque España era muy consciente del hecho que no tenía la fuerza en hombres, el dinero ni la armada para defender adecuadamente todos los territorios que reclamaba en las Antillas [...], Inglaterra, por otro lado, no había podido establecer bases comerciales permanentes en la región para romper el monopolio comercial español» ${ }^{127}$. Sin embargo, sus implicaciones fueron devastadoras. En palabras del gobernador Suárez de Amaya, las consecuencias de las continuas victorias enemigas sobre las posesiones de España representaron «la pérdida de reputación de nuestra valerosa nación» ${ }^{128}$.

\section{REFERENCIAS BIBLIOGRÁFICAS}

Andrews, Kenneth R., The Spanish Caribbean: Trade and Plunder, 1530-1630, New Haven, Yale University Press, 1978.

Arráiz Lucca, Rafael, Venezuela: 1498-1728. Conquista y urbanización, Caracas, Editorial Alfa, 2013.

Cardelús, Borja y Fernández Toraño, Antonio, La Florida española, Madrid, Ediciones Polifemo, 2013.

Elliott, John H., España, Europa y el mundo de Ultramar (1500-1800), Madrid, Taurus, 2010.

Elliott, John H., Imperios del mundo Atlántico. España y Gran Bretaña en América, 1492-1830, Madrid, Taurus, 2011.

Gaztambide-Géigel, Antonio, Tan lejos de Dios... ensayos sobre las relaciones del Caribe con Estados Unidos, San Juan / La Habana, Ediciones Callejón, 2006.

Goodwin, Robert, Spain. The Centre of the World, 1519-1682, Londres, Bloomsbury, 2016.

127 Watts, 1998: 131-132.

128 Carta de Diego Suárez de Amaya, gobernador de Cumaná, 15 de junio de 1602, AGI, SD 187, r. 3, n. $^{\circ} 10$, f. $1 \mathrm{v}$. 
Hakluyt, Richard, The Principal Navigations, Traffiques, and Discoveries of the English Nation, Edinburgo, Escocia, E\&G Goldsmid, 1890, tomado de https:// archive.org/stream/cihm_33131\#page/n327/mode/2up.

Kennedy, Dane, "Imperial History and Post-Colonial Theory", The Journal of Imperial and Commonwealth History, 24/3 (Londres, 1996): 345-363.

Kristzler, Edward, Jewish Pirates of the Caribbean, Nueva York, Anchor Books, 2008.

Lane, Kris E., "Corsarios, piratas y la defensa de Cartagena de Indias en el siglo XVI", Haroldo Calvo Stevenson y Adolfo Meisel Roca (eds.), Cartagena de Indias en el siglo XVI, Cartagena, Banco de la República de Colombia, 2009: 105-124.

Losada, Juan Carlos, Historia de las guerras de España. De la conquista de Granada a la guerra de Irak, Barcelona, Pasado \& Presente, 2015.

Marrero, Leví, Cuba: Economía y sociedad. Tomo 2, Siglo XVI, Madrid, Editorial Playor, 1974.

Marrero, Leví, Cuba: Economía y sociedad. Tomo 3, el siglo XVII (I), Madrid, Editorial Playor, 1975.

Morales Carrión, Arturo, Puerto Rico y la lucha por la hegemonía en el Caribe. Colonialismo y contrabando, siglos XVI-XVIII, San Juan, Centro de Investigaciones Históricas, Editorial de la Universidad de Puerto Rico, 2003.

Morales Padrón, Francisco, Spanish Jamaica, Kingston, The Jamaica National Heritage Trust, 2003.

Moya Pons, Frank, Historia del Caribe. Azúcar y plantaciones en el mundo atlántico, Santo Domingo, Ediciones Ferilibro, 2008a.

Moya Pons, Frank, Manual de historia dominicana, Santo Domingo, Caribbean $\mathrm{Pu}-$ blishers, 2008b.

Pestana, Carla Gardina, The English Conquest of Jamaica. Oliver Cromwell's Bid for Empire, Cambridge / Londres, The Belknap Press of Harvard University Press, 2017.

Pinto Soria, Julio (ed.), Historia general de Centroamérica. Tomo II: El régimen colonial, Madrid, Ediciones Siruela, 1993.

Raleigh, Walter, The Discovery of Guiana, Gutenberg Project, http://www.gutenberg. org/files/2272/2272-h/2272-h.htm.

San Juan, Víctor, Breve historia de la Armada Invencible, Madrid, Nowtilus, 2017.

Southey, Thomas, Chronological History of the West Indies by Captain Thomas Southey, Commander, Royal Navy, Londres, Longman, Rees, Orme, Brown and Green, 1829, vol. 1.

Thomas, Hugh, El señor del mundo. Felipe II y su imperio, Barcelona, Planeta, 2013. 
Vidal Ortega, Antonino y Baquero Montoya, Álvaro (comps.), De las Indias remotas...Cartas del Cabildo de Santa Marta (1529-1640), Barranquilla, Ediciones Uninorte, 2007.

Vila Vilar, Enriqueta, "El espacio Caribe y la gobernación de Puerto Rico como modelo de tres continentes", León-Borja István Szászdi (ed.), Historia de las gobernaciones atlánticas en el Nuevo Mundo. Actas, Río Piedras, La Editorial de la Universidad de Puerto Rico, 2011.

Watts, David, The West Indies. Patterns of Development, Culture and Environmental Change since 1492, Cambridge, Cambridge University Press, 1998.

Williams, Eric, From Columbus to Castro. The History of the Caribbean, Nueva York, Vintage Books, 1984.

Fecha de recepción: 22 de septiembre de 2019.

Fecha de aceptación: 14 de febrero de 2020.

\section{"To own the Indies": English attacks on the Spanish Caribbean, $1590-1620$}

By the end of the sixteenth century, the Spanish empire in America had suffered military and moral defeats that stained its prestige as a world power. After the failed invasion of the British Isles in 1586, Spain lost much more than its fleet: it also lost the respect of the English, who embarked on a programme of open aggression on Spanish possessions in the Americas. This essay portrays the colonies' situation in the last decade of the sixteenth and the first two decades of the seventeenth century, and the desperate vulnerability of the Caribbean facing enemy attacks. With reference to correspondence from governors and the Real Audiencia appellate courts, the paper presents a combined look at attacks on the region by English aggressors, some of whom are better known than others.

KEY WORDS: English attacks; corsairs; war; defence; soldiers; Drake; Cumberland; Caribbean; sixteenth century; seventeenth century. 
